\title{
Cooperative, Synectics, and CTL Learning Models toward Speaking Ability Viewed from Student's Motivation
}

\author{
Agus Darmuki \\ Sebelas Maret Surakarta State University \\ Surakarta, Indonesia \\ agus_darmuki@yahoo.co.id \\ Andayani \\ Sebelas Maret Surakarta State University \\ Surakarta, Indonesia, \\ bu_anda09@yahoo.co.id
}

\author{
Joko Nurkamto \\ Sebelas Maret Surakarta State University, \\ Surakarta, Indonesia, \\ jokonurkamto@gmail.com \\ Kundharu Saddhono \\ Sebelas Maret Surakarta State University, \\ Surakarta, Indonesia, \\ kundharu@uns.ac.id
}

\begin{abstract}
The goal of Speaking Course in higher education is to develop student's ability to speak effectively. The aim of this research are: 1) to investigate the differences on students' speaking ability taught by Cooperative, Synectics, and CTL learning models, 2) to find the differences of speaking ability among the students with high motivation and low one, 3) to know the interactions between learning model and motivation toward speaking ability. This quasi experimental research used factorial design $3 \times 2$. The data were collected through questionnaire for measuring students' motivation for speaking, empirical test for knowing the validity and reliability of instruments as well as speaking test to measure speaking achievement. The research results showed that there were interactions between learning models and motivation for speaking toward speaking ability. The speaking score of students with high motivation and taught by cooperative learning model was better than them with synectics and CTL.
\end{abstract}

Keywords—cooperative; synectics; CTL; motivation; speaking

\section{INTRODUCTION}

Speaking is the ability to convey messages orally. [1] argue that speaking means the ability to pronounce language sounds to express or deliver thoughts, ideas, and feelings orally. [2] said that speaking is the second language activity done by human after listening. Speaking refers to the ability to pronounce words (sound articulation) expressed to convey ideas or thoughts. It gives great contribution for students to have better communication skill [3].

Speaking becomes one of courses in higher education, particularly in the Department of Indonesian Language Education. The goal of Speaking course is to develop effective student' speaking ability. Effective communication happens when the delivered message is accepted well by the receiver [4]. Students as teacher candidates have to process information well for the sake of having effective speaking. Processing information belongs to a learning process [5] and it becomes one of components for teachers' success as they have to give understandable explanation. [6] states that the teacher success is determined by the attitudes of care, never give up, understandable explanation (method/model), and good classroom management.

The lecture process of speaking course found that many students lacked of speaking ability. They did not give responses during the teaching and learning process in class. They spoke unconfidently; even their ideas were delivered in a jump-way. They have low motivation to speak because few students responded the lecturer questions, while many students kept quiet.

Motivation for achievement as motive that encourages individual to reach success and achieve results in certain standards. Motivation for achievement is internal support of students who comes from himself to finish learning activity and obtain success maximally [7]. It is inside power of students which trigger passion in learning activity and guarantee its sustainability [8]. Therefore, a subject must have motivation to achieve the best result. Motivation can be defines as student's thrust to do something so that he/she has curiosity in learning. Motivation has to be built by a lecturer by playing role as a motivator to improve learning liveliness/interaction.

[9] state seven indicators to measure high and low motivation for achievement as the following: (1) work ethic, (2) acquisitiveness, (3) dominance, (4) excellence, (5) status aspiration, (6) competitiveness, (7) mastery. Students are expected to have high motivation for achievement so that they can achieve maximum learning outcomes. The development of creativity and liveliness of students is very crucial during the learning process. Creativity is very essential in life as it enables human to improve his life quality [10]. Students' creativity is needed in learning speaking. 
[11] interprets learning as a combination composed from humanized elements, material, facility, equipment, and procedure which complete and influence one to another to achieve learning objectives. [12] defines learning method as a way used by a teacher to have relation with students during the learning process. Thus, learning method is a way carried out by a teacher/lecturer to achieve the determined goal. Therefore, before presenting the learning materials, a lecturer has to choose certain method which is appropriate to the materials. [13] explains that learning method is ways to present learning materials done by educators so that students have learning experience to achieve the goal. In essence, learning method is a way that carried out, related to working patterns to understand the objects of lesson target in order to achieve learning objectives designed by the lecturer.

Learning method has to arouse students' achievement, consider the process and result, and equalize theory as well as practice. [13] says that learning, ideally, does not only focus on the process but also on the result so that the learning objective can be achieved maximally. Learning in past put great emphasis on the target achievement of result not process and the main crucial thing is the number of learning materials not the depth of learning materials. Thus, lecturers have methodological problem in terms of choosing their learning strategy [2].

Selecting learning method for speaking necessarily aims to improve students' motivation, process, and learning outcomes. Teaching speaking effectively needs revamping in all components inside. One of which is choosing the learning model. Students have to obtain not only theoretical experience but also practical one in learning speaking as the last kind of experience enables the improvement of students speaking ability receptively and productively.

Nowadays, various learning models have been applied to renew effective and efficient learning by embedding motivation for lifelong education. The selection of learning model must focus optimally on the improvement of motivation, process, and learning outcomes. Lecturers are demanded to choose the appropriate learning model, particularly in teaching speaking. They have to acquire the knowledge and mastery of various learning models not only theoretically but also practically.

Some learning models are good and appropriate to be implemented in teaching Speaking course such as synectics, cooperative, and CTL. [14] states that synectics learning model is metaphor activity consisting of personal and direct analogies. [15] presents synectics learning model as metaphorical process with analogy. This model unifies various elements by using metaphor to have new vision.

[16] describes cooperative learning model as a learning strategy involving students to work participatively and cooperatively in achieving the goal. During this learning model, students work in small groups and help each other to learn materials [17]. Cooperative learning model can be used by lecturers to develop creativity personally or in group. This model is designed to distribute responsibility among students during the learning process and orientate for social competence [18][19][20][21][22]. Students were chosen as the research subjects because during their age, they are characterized by high curiosity to have experience, insight, knowledge, character building, and language skill with which they can be ready and able to adapt the recent and future life.

[24] defines CTL (Contextual Teaching and Learning) as a learning concept which assists teachers to correlate their learning materials with the reality and encourages students to correlate their knowledge and its application in their daily lives. It can be conducted by involving seven components of effective learning as follows: constructivism, questioning, inquiry, learning community, modeling, and authentic assessment. [24] describes CTL as an educational process which aims at assisting students to get the meaning of their learning materials by connecting academic subjects with their daily lives contexts i.e. personal, social, and cultural contexts.

\section{METHODS}

This quasi experimental research used factorial design $3 \times 2$. The population of this study is all students of Faculty of Teacher Training and Education, the sample is taken by random sampling of 150 students in each study program of Indonesian Language and Literature Education. Data collection techniques through questionnaire for measuring students' motivation for speaking, empirical test for knowing the validity and reliability of instruments as well as speaking test to measure speaking achievement. The 22 questionnaire statements were distributed to students. The speaking test consists of 25 questions of multiple choices and oral test.

\section{RESULT AND DISCUSSION}

\section{A. Students Speaking Ability Taught by Cooperative Learning Model}

The descriptive analysis on the collected data of students speaking ability taught by cooperative learning model indicated that $\mathrm{n}=150$, minimum $(\mathrm{min})$ score $=59$, maximum $(\max )$ score $=96$, Mean $(\mathrm{Mn})=78.07$, Median $(\mathrm{Me})=80.00$, Modus $(\mathrm{Mo})=84.00$, deviation standard $(\mathrm{S})=9.77$, and variance $\left(\mathrm{S}^{2}\right)=95.45$.

TABLE I. DISTRIBUTION OF STUDENTS SPEAKING ABILITY FREQUENCY TAUGHT BY COOPERATIVE LEARNING MODEL

\begin{tabular}{|c|c|c|}
\hline Interval Class & Frequency & Procentage \\
\hline $59-64$ & 22 & $14.67 \%$ \\
$65-69$ & 10 & $6.67 \%$ \\
$70-74$ & 20 & $13.33 \%$ \\
$75-79$ & 22 & $14.67 \%$ \\
$80-84$ & 31 & $22.67 \%$ \\
$85-89$ & 25 & $16.67 \%$ \\
$90-94$ & 12 & $8.00 \%$ \\
$95-99$ & 5 & $3.33 \%$ \\
\hline
\end{tabular}

The students taught by cooperative model gave high motivation in speaking skill. This model is effective for learning speaking. The frequency distribution can be briefly presented in histogram as follows: 


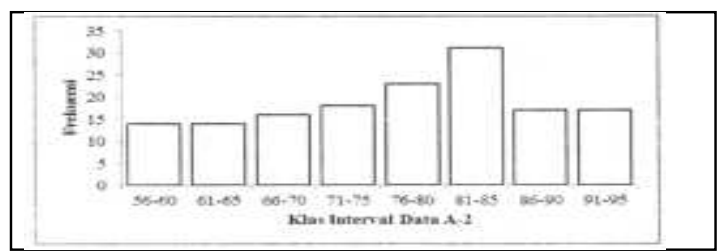

Fig. 1. Histogram Distribution of Students Speaking Ability Frequency Taught by Cooperative Learning Model.

Notes: $\mathrm{n}=150 ; \min =59 ; \max =96 ; \mathrm{Mn}=78.07 ; \mathrm{Me}=80.00$; $\mathrm{Mo}=84.00 ; \mathrm{S}=9.77 ; \mathrm{S}^{2}=95.45$

\section{B. Students Speaking Ability Taught by Synectics Learning Model}

The descriptive analysis on the data of students speaking ability taught by synectics learning model showed that: $\mathrm{n}=$ 150 , minimum $(\min )$ score $=56$, maximum score $(\max )=93$, mean $(\mathrm{Mn})$ is similar to median $(\mathrm{Me})=78$, modus $(\mathrm{Mo})=$ 60.00 , deviation standard $=10.24$, variances $\left(\mathrm{S}^{2}\right)=104.76$. Based on the data analysis, Sturges-based frequency distribution was listed in Table 2 with range $=37$, number of interval class $(\mathrm{k})=8$ and interval length $(\mathrm{C})=5$ as the following.

TABLE II. FREQUENCY DISTRIBUTION OF STUDENTS SPEAKING ABILITY TAUGHT BY SYNECTICS LEARNING MODEL

\begin{tabular}{|c|c|c|}
\hline Interval Class & Frequency & Procentage \\
\hline $56-60$ & 14 & $9.33 \%$ \\
$61-65$ & 14 & $9.33 \%$ \\
$66-70$ & 16 & $10.67 \%$ \\
$71-75$ & 18 & $12.00 \%$ \\
$76-80$ & 23 & $15.33 \%$ \\
$81-85$ & 31 & $20.67 \%$ \\
$86-90$ & 17 & $11.33 \%$ \\
$91-95$ & 17 & $11.33 \%$ \\
\hline
\end{tabular}

Based on the data in Table 2, it can be stated that synectics learning model gave effective influence on speaking learning process although it was not as significant as cooperative model.

Frequency distribution in Table 2 can be presented in histogram as follows:

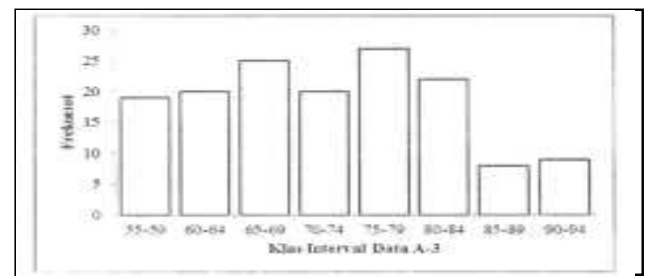

Fig. 2. Histogram Frequency Distribution of Students Speaking Ability Taught by Synectics Learning Model

Notes: $\mathrm{n}=150 ; \min =56 ; \max =93 ; \mathrm{Mn}=76.90 ; \mathrm{Me}=78.00$; $\mathrm{Mo}=60.00 ; \mathrm{S}=10.24 ; \mathrm{S}^{2}=104.76$

\section{Students Speaking Ability Taught by CTL Learning Model}

Descriptive analysis on students speaking ability showed that: $\mathrm{n}=150$, minimum $(\min )$ score $=55$, maximum score $(\max )=$ 94, mean $(\mathrm{Mn})=72.34$, median $(\mathrm{Me})=73.00$, modus $(\mathrm{Mo})=$ 83.00, deviation standard $=9.97$, variances $\left(\mathrm{S}^{2}\right)=99.34$. Based on the data analysis, Sturges-based frequency distribution was listed in Table 2 with range $=39$, number of interval class $(\mathrm{k})=$ 8 and interval length $(C)=5$ as the following.

TABLE III. FREQUENCY DISTRIBUTION OF STUDENTS SPEAKING ABILITY TAUGHT BY CTL LEARNING MODEL

\begin{tabular}{|c|c|c|}
\hline Interval Class & Frequency & Procentage \\
\hline $55-59$ & 19 & $12.67 \%$ \\
$60-64$ & 20 & $13.33 \%$ \\
$65-69$ & 25 & $16.67 \%$ \\
$70-74$ & 20 & $13.33 \%$ \\
$75-79$ & 27 & $18.00 \%$ \\
$80-84$ & 22 & $14.67 \%$ \\
$85-89$ & 8 & $5.33 \%$ \\
$90-94$ & 9 & $6.00 \%$ \\
\hline
\end{tabular}

Based on the data in Table 3, it can be stated that CTL learning model gave effective influence on speaking learning process although it was not as significant as cooperative model.

Frequency distribution in Table 3 can be presented in histogram as follows:

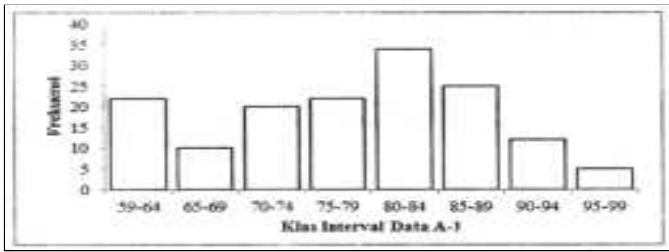

Fig. 3. Frequency Distribution of Students Speaking Ability Taught by CTL Learning Model

Notes: $\mathrm{n}=150 ; \min =55 ; \max =94 ; \mathrm{Mn}=72.34 ; \mathrm{Me}=73.00$; $\mathrm{Mo}=83.00 ; \mathrm{S}=9.97 .24 ; \mathrm{S}^{2}=99.34$

The questionnaire result on the motivation from the three learning models showed that cooperative learning model is more effective than synectics and CTL ones. High motivation influences speaking ability effectively.

\section{Students Speaking Ability Viewed from The Average of Each Data Cell on Learning Motivation}

The data analysis on speaking ability in this research leads to the result of two-way variance analysis which processing used SPSS version 17. Table 4 presents the students speaking ability viewed from the average score in each data cell of learning motivation.

TABLE IV. The AVERAge Score of EACH Data CELL

\begin{tabular}{|c|c|c|c|c|}
\hline No & $\begin{array}{c}\text { Learning Model } \\
(\mathrm{A})\end{array}$ & \multicolumn{2}{|c|}{ Learning Motivation } & \multirow{2}{*}{$\begin{array}{c}\text { Marginal } \\
\text { Average }\end{array}$} \\
\cline { 3 - 4 } & & $\begin{array}{c}\text { High } \\
(\mathrm{B} 1)\end{array}$ & $\begin{array}{c}\text { Low } \\
(\mathrm{B} 2)\end{array}$ & \\
\hline 1 & Cooperative & 3.632 & 3.405 & 3.566 \\
\hline 2 & Synectics & 3.335 & 3.359 & 3.264 \\
\hline 3 & CTL & 3.471 & 3.452 & 3.398 \\
\hline & Total & 3.479 & 3.405 & \\
\hline
\end{tabular}




\section{E. Interaction Among Learning Model and Motivation in Influencing Students Speaking Ability}

The detailed interaction was found by inter-cell double comparison. The significance score of double comparison was processed by SPSS version 17 as presented in Table 5 .

TABLE V. INTER-CELL COMPARISON IN THE SAME COLUMN AND Row

\begin{tabular}{|c|c|c|c|c|}
\hline No & Comparison & Sig $\mathbf{P}$ & $\operatorname{Sig} \alpha$ & Judgment \\
\hline 1 & $\begin{array}{l}\text { High motivation } \\
\text { (A1B1) and low motivation } \\
\text { Synectics(A2B1) }\end{array}$ & 0.00 & 0.05 & $\begin{array}{l}\mathrm{H} 0 \\
\text { Rejected }\end{array}$ \\
\hline 2 & $\begin{array}{l}\text { High motivation Cooperative } \\
\text { (A1B1) and high motivation CTL } \\
(\mathrm{A} 3 \mathrm{~B} 1)\end{array}$ & 0.07 & 0.05 & $\begin{array}{l}\text { H0 } \\
\text { Accepted }\end{array}$ \\
\hline 3 & $\begin{array}{l}\text { High motivation CTL (A3B1) and } \\
\text { high motivation Synectics (A2B1) }\end{array}$ & 0.23 & 0.05 & $\begin{array}{c}\mathrm{H} 0 \\
\text { Accepted }\end{array}$ \\
\hline 4 & $\begin{array}{l}\text { Low motivation } \\
\text { (A1B2) and low motivation } \\
\text { Synectics (A2B2) }\end{array}$ & 0.99 & 0.05 & $\begin{array}{c}\mathrm{H} 0 \\
\text { Accepted }\end{array}$ \\
\hline 5 & $\begin{array}{l}\text { Low motivation Cooperative } \\
(\mathrm{A} 1 \mathrm{~B} 2) \text { and low motivation CTL } \\
(\mathrm{A} 3 \mathrm{~B} 2)\end{array}$ & 0.99 & 0.05 & $\begin{array}{c}\mathrm{H} 0 \\
\text { Accepted }\end{array}$ \\
\hline 6 & $\begin{array}{l}\text { Low motivation CTL (A3B2) and } \\
\text { low motivation Synectics (A2B2) }\end{array}$ & 0.79 & 0.05 & $\begin{array}{c}\mathrm{H} 0 \\
\text { Accepted }\end{array}$ \\
\hline 7 & $\begin{array}{l}\text { High motivation } \\
\text { (A1B2) and low } \\
\text { Cooperative (A1B2) }\end{array}$ & 0.01 & 0.05 & $\begin{array}{c}\mathrm{H} 0 \\
\text { Accepted }\end{array}$ \\
\hline 8 & $\begin{array}{l}\text { High motivation Synectics (A2B1) } \\
\text { and Low motivation Synectics } \\
(\mathrm{A} 2 \mathrm{~B} 2)\end{array}$ & 0.90 & 0.05 & $\begin{array}{c}\mathrm{H} 0 \\
\text { Accepted }\end{array}$ \\
\hline 9 & $\begin{array}{l}\text { High motivation CTL (A3B1) and } \\
\text { low motivation CTL (A3B2) }\end{array}$ & 0.10 & 0.05 & $\begin{array}{c}\mathrm{H} 0 \\
\text { Accepted } \\
\end{array}$ \\
\hline
\end{tabular}

\section{CONCLUSIONS}

Normality and homogeneity tests were used prior to testing hypothesis. Since the data analysis by SPSS program was employed, Barlette and Lilliefors were used to test normality and homogeneity. The results of the first test showed that the data came from population with normal distribution while that of the last one indicated the same population variants.

The hypothesis testing obtained the score of F-calculation 17.267. After consulted by the significance level 0.005 with the numerator 2 and denominator 445, the score of F-table was 3.00. It means that F-calculation is greater than F-table $(17.267>3.00)$. The results of Scheffe analysis indicated: (1) the comparison between synectics and CTL learning models had the score of F-calculation 7.18 greater than F-table 3.00; (2) the comparison between CTL and cooperative learning models had the score of F-calculation 36.13 greater than Ftable 3.00 ; (3) the comparison between synectics and cooperative learning models had the score of F-calculation 11.09 greater than F-table 3.00. In short, cooperative learning model is better applied for learning speaking than synectics and CTL methods. CTL, synectics, and cooperative learning model gave effects on students speaking ability.

Based on the results of hypothesis testing, F-calculation was 13.964. After consulted by significance level 0.05 with the numerator 1 and the denominator 445, F-table was 3.84. It means that F-calculation is greater than F-table $(13.964>3.84)$. Scheffe analysis showed that F-calculation 11.97 greater than
F-table 3.84. In essence, there were effects between speaking ability and motivation for achievement both high and low.

The result of a two-way variance analysis gained the significance score $0.003>0.05$ which means that the hypothesis was rejected. In other words, there were interactions among the three learning models i.e. cooperative, synectics, and CTL as well as motivation toward students speaking ability. The speaking score of students with high motivation and taught by cooperative learning model was better than them with synectics and CTL.

The conclusions of research are as follows: first, there was significant different among the students taught by the learning models of CTL, synectics, and cooperative. Positive feelings (happiness, togetherness, and less anxiety) can control mental and cognitive processing optimally which then lead to high motivated to have public speaking. Second, motivation for achievement both high and low gave effect to students speaking ability. The students with high motivation have the ability to cooperate than them with low motivation. Third, the interaction between learning model and motivation for achievement influenced the students speaking ability. Based on inter-cells comparison namely the interaction between column and row, it was found that 6 comparisons showed the similarity and 3 comparisons showed distinction. Therefore, lecturers are suggested to choose appropriate learning model by referring to the characteristics of students' motivation for achievement, their ability, and learning materials so that they can guide students to obtain experience and build their characters. Every lecturer is recommended to have good knowledge on various learning models both theoretical and practical.

\section{ACKNOWLEDGEMENT}

This research project was supported by a grant from the Ministry of Research Technology and Higher Education, Indonesia.

\section{REFERENCES}

[1] Brown G. \& G. Yule. (2012). Teaching the Spoken Language. London: Cambridge University Press.

[2] Nurgiantoro, Burhan . (2011). Penilaian dalam Pembelajaran Bahasa dan Sastra. Yogyakarta: BPFE.

[3] Rido, Akhyar, Noraini Ibrahim \& Radha M.K. Nambiar. (2013). Interaction Strategies of Master Teacher in Indonesian Vocational Classroom: A case Study. 3L Journal of Language Teaching, Linguistics and Literature.21(3): 85-98.

[4] Daryanto. (2010). Ilmu Komunikasi. Bandung: Satu Nusa.

[5] Wardani, I.G.A.K, Prasetyo Irawan, Suciati. (2007). Teori Belajar, Motivasi dan Keterampilan Mengajar. Pekerti. Dirjen Dikti, Depdikbud.

[6] Marland, Michael. (2010). Seni Mengelola Kelas : Tugas dan Penampilan Seorang Pendidik. Semarang : Dahar Prize.

[7] Abdullah, Mat Zaini, Rafisah Osman. (2015). Kesan Pengantaraan Pengalaman Psikologi bagi Hubungan Pelbagai Kemahiran dalam Tugas Pengajaran dengan Motivasi Kerja Guru. Malaysian Journal of Learning \& Instruction. 12. 205-233.

[8] Abdullah, Melissa Ng Lee Yen. (2016). Interaction effects of gender and motivational beliefs on self-regulated learning: a study at ict-integrated schools. Malaysian Journal of Learning \& Instruction. 13 (1). 24-41.

[9] Lynn, Richard \& Tony Cassidy. (1989). "A Multyfactorial Approach to Achievement Motivation The Development of a Comprehensive Measure"; Journal of Occupational Psychology. 2(62). 301-312. 
[10] Darmuki, A., Andayani, Joko Nurkamto, Kundharu Saddhono. (2017). Evaluating Information-Processing-Based Learning Cooperative Model on Speaking Skill Course. Journal of Language Teaching and Reasearch. 8(1) pp. 44-51.

[11] Hamalik, Oemar. (2008). Pengembangan Kurikulum KTSP. Bandung: Rosda Karya

[12] Sudjana, Nana. (2015). Penilaian Hasil Proses Belajar Mengajar. Bandung: Remaja Rosdakarya.

[13] Andayani. (2015). Problema dan Aksioma dalam Metodologi Pembelajaran Bahasa Indonesia. Yogyakarta: Deeppublish.

[14] Suryaman. 2004. "Penerapan Model Pembelajaran Suatu Inovasi di Perguruan Tinggi (Tantangan Umum Pendidikan Tinggi)" Jurnal Pendidikan IKIP PGRI Madiun. 10 (1). 11-14.

[15] Gordon, W. J. J. (2009). Synectics. New York: Macmillan.

[16] Kauchak, Donald P. and Eggan, Paul D. 1996. Learning and Teaching, Research-Based Method Needham Heihts. New York: Allyn and Bacon Publisher.

[17] Slavin, Robert E. (1995). Cooperative Learning: Theory, Research and Practice. Massachusetts: Allyn and Bacon Publisher.

[18] Barkley, Elizabert E. (2012). Collaborative Learning Techniques. San Francisco: Jossey-Bass, 2005, (Edisi Terjemahan oleh Elizabert E Barkley. Bandung: Nusa Media).

[19] Klimoviene, Giedre. (2006). "Using Cooperative Learning to Develop Language Competence and Social Skill'. Studies About Languages. Vol. 8, pp. 77-83.

[20] Meng, Jing. (2010). "Cooperative Learning Method in the Practice of English Reading and Speaking". Journal of Langguage Teaching and Research. 1(5). 701-703.

[21] Talebi, Ferina. (2012). "The Impact of Cooperative Learning on Oral Proficiency”. Mediterranean Journal of Social Sciences. 3.(3). 75-79.

[22] Thuy, Le Thi Bich. (2005). "An Action Research on the Application of cooperative Learning to Teaching Speaking". TESOL. Journal. 1. 332349.

[23] Undang-Undang Nomor 20 Tahun 2003 Tentang Sistem Pendidikan Nasional

[24] Johnson, D.W. (2006). Reaching Out: Interpersonal Effectiveness and Self-Actualization. 9th ed. Boston: Pearson.

[25] Depdiknas. (2003). Pendekatan Kontekstual (Contextual Teaching and Learning, CTL) Jakarta : Depdiknas. 